CASE REPORT

\title{
Primary Renal Squamous Cell Carcinoma
}

\author{
*SM Badruddoza1, Shahnaz Pervin² \\ ${ }^{1}$ Prof. Dr. SM Badruddoza, Department of Pathology, Rajshahi Medical College, Bangladesh \\ ${ }^{2}$ Dr.Shahnaz Pervin, Department of Pathology, Rajshahi Medical College, Bangladesh \\ * Corresponding author
}

\begin{abstract}
Primary renal squamous cell carcinoma is a very rare tumour. Only a few cases have been reported in world literature. Here we report a case with renal squamous cell carcinoma. The patient presented with flank pain, fever and vomiting. In ultrasonography, renal mass was detected and after nephrectomy followed by histopathological examination, it was diagnosed as squamous cell carcinoma. There was no evidence of renal calculi or other predisposing factors. This report highlights the rarity of the tumour.
\end{abstract}

Key words: Renal, Carcinoma, Squamous Cell

\section{Introduction}

Primary neoplasms of the renal collecting system are uncommon accounting for only $4 \%$ to $5 \%$ of all urothelial tumours. The transitional cell type is the most frequently diagnosed (85\%-95\%) followed by squamous cell carcinoma (6\%$15 \%)^{1}$. Squamous cell carcinoma of the renal pelvis is a rare tumour. The incidence of this tumour is $1.4 \%$ of all renal malignancy 2 . Primary renal squamous cell carcinoma is a very rare tumour and few cases have been reported in world literature 3 .

\section{Case Report}

A 40 year old female patient presented with complaints of pain in the left flank, fever and vomiting for 4 months. Physical examination was unremarkable. Routine haematology revealed high ESR (110 $\mathrm{mm}$ in 1st hour in westergren method), neutrophilic leucocytosis and moderate degree of normochromic normocytic anemia. Urine analysis, biochemical tests and chest radiograph were normal except proteinuria. Ultrasonography of whole abdomen showed enlarged left kidney with loss of normal renal architecture and a large mass measuring $(5.9 \times 4.8) \mathrm{cm}$ occupying lateral aspect of its parenchyma and there was no evidence of hydronephrosis or stone. Right AKMMC J 2012: 3(2): 34-36 kidney and both the ureters were normal. Urinary bladder was wellfilled and normal in wall thickness. A few of paracaval and paraumbillical lymph nodes were enlarged but there was no ascites. Plain X-ray of KUB region revealed no stone. Intravenous urography showed distorted and compresed pelvicalyceal system of left kidney with normal excreting urogram. There was no history of past radiation exposure or renal stone. The patient under went left sided nephrectomy. There was no involvement of retroperitoneal soft tissue or regional lymph nodes. (Pathological stage T2NOMO). On gross examination, the kidney was larger in size measuring $(12 \times 6) \mathrm{cm}$. Cut surface revealed replacement of most of the renal cortical parenchyma by grayish white tumour. Growth of tumour was infiltrating in nature.

Histopathological examination revealed features of moderately differentiated invasive squamous cell carcinoma with areas of extensive necrosis and comedo pattern. It also revealed compressed unremarkable glomeruli and tubules. After 2 months of nephrectomy, the patient felt recurrent left flank pain and ultrasonography showed another mass of $(4 \times 3) \mathrm{cm}$ occupied the left renal fossa. The patient then started taking radiotherapy. 
Primary renal squamous cell carcinoma

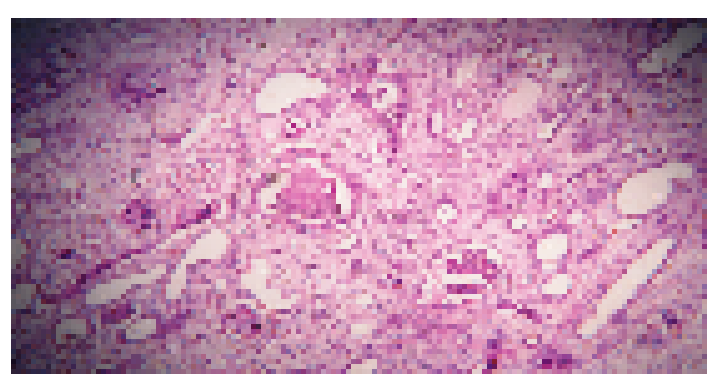

Fig.1: Histological section showing moderately differentiated invasive squamous cell carcinoma with areas of extensive necrosis and comedo pattern. $\quad(H \& E$ $\times 100$ )

\section{Discussion}

Primary renal squamous cell carcinoma is a rare cancer with a variable incidence of about. 5-15\% of all urothelial cancer ${ }^{4}$. Pure squamous cell carcinoma is very rare though it is the second most common tumour in the renal pelvis ${ }^{1}$. Chronic irritation of urothelium is presumed to be a cause of squamous metaplasia with subsequent malignant preogression to squamous cell carcinoma. Common causes of chronic irritation are renal calculus disease for long duration, previous history of renal calculous surgery, chronic analgesic abuse or radiotherapy. The strongest association has been reported with renal calculous disease specially with impacted staghorn calculi existing for a long duration ${ }^{3}$. Smoking or tobacco chewing was also observed in $60 \%$ of the patients as a known predisposing factor ${ }^{5}$.

In a series of 4 patients with squamous cell carcinoma of renal pelvis, mean age was $60 \mathrm{yrs}$. M: F was 3:1, right to left side ratio was $1: 1$ and most common presenting symptom was flank pain and haematuria. In $100 \%$ of cases, there was presence of staghorn type of renal stones 6 .

Renal pelvic tumours are almost never palpable clinically, however they may block the urinary out flow and lead to palpable hydronephrosis. Hydronephrosis is more common in renal tumour than renal pelvic ones 2 . In $50 \%$ of renal pelvic tumours there is precxisting or concomitant bladder urothelial tumour 5 . However cases have been reported in which no apparent etiological factors could be detected ${ }^{2}$.
The tumour can be documented by conventional radiological imaging modalitis. Filling defects or obstructive lesions in the renal pelvis by intravenous/retrograde urography or detection of a solid mass by ultrasonography can be the signs of the tumour. Tomographic imaging reveals these findings more specifically.

In general, these tumours are highly aggressive and are at high stage when detected. Most of them are histologically high grade and outcome is generally unfavorable. Extensive infiltration of the renal parenchyma and retroperitoneal soft tissues are very common 7 . In one series, $84 \%$ of the tumour were found at operation to be locally advanced or metastatic 8 . The prognosis was very poor. The current primary treatment of renal squamous cell carcinoma is nephrectomy with or without ureterectomy 3 followed by radiotherapy and chemotherapy.

In the present case the patient was 40 yrs old, relatively younger, presented with flank pain, fever and vomiting. No associated etiological factors like (Calculi, hydronephrosis, analgesic abuse, smoking or tobacco chewing) could be detected. IVU showed distorted and compressed left. pelvicalyceal system but normal excreting urogram. Grossly, infiltrative pattern of tumour mass occupied most of the renal parenchyma was seen. So the origin of the tumour was from renal parenchyma not from renal pelvis. Few cases of primary squamous cell carcinoma of kidney have been reported ${ }^{3}$. Two months after nephrectomy, because of recurrent pain, follow up ultrasonography revealed a mass $(4 \times 3) \mathrm{cm}$ occupied the left renal fossa indicating possible recurrence and aggressiveness of the tumour. Although radiotherapy was started but, if metastasis develops, adjuvant chemotherapy or radiotherapy has little effect on the unfavorable prognosis 1,4 .

\section{Conclusion}

Squamous cell carcinoma of urothelial tract particularly renal pelvis is thought to arise through a process of metaplasia of urothelium. Various etiological factors are responsible for squamous metaplasia and subsequent carcinoma. 
In this case no such etiological factor could be identified and the origin of tumour was from renal parenchyma rather than the pelvis. This report describes one of the rare tumour of renal origin, the cause of which is to be sought for.

\section{References}

1. Karabulut A, Emir L, Gonultas $\mathrm{M}$, Incel $\mathrm{N}$, Germiyanoglu C, et al. Squamous cell carcinoma located in the renal calyceal system; A case report and review of the literature. Turk J cancer 2002; 32 (I): $20-24$.

2. Bandyopadhyoy R, Biswas S, Nag D, Ghosh AK. Squamous cell carcinoma of the renal pelvis presenting as hydronephrosis. J can Res ther 2010; 6 : 537-539

3. Singh V, Sinha RJ, Sankhwar SN, Mehrotra B, Ahmed N, et al. Squamous cell carcinoma of the kidney-rarity redefined; Case series with review of literature. J Cancer Sci Ther.2010; 2(4): 55-6
4. Verma N, Yadav G, Dhawan N. Kumar A. Squamous cell carcinoma of kidney Co-existing with renal calculi: a rare tumour,2011. BMJ case reports.

5. Al pers C. E 2010. The kidney in Kumar V, Abbus AK, Fausto $\mathrm{N}$ and Aster J.C, Pathologic basis of disease, Saunders. Philadedphila, USA, 8th ed. PP967.

6. Jain A. Mittal D, Jindal A, Solanki R, Khatri S et al. Incidentally detected squamous cell carcinoma of renal pelvis in patients with staghorn calculi; case series with review of the literature.2011, ESRN Oncology. Vol. 2011

7. Fletcher CDM, 2007. Tumours of the urinary tract; Diagnostic Histopathology of tumours Elsevier, Philadelphia 3rd ed PP-522-523.

8. Rosai J, 2004. Urinary tract, surgical pathology MOSBY, st louis USA 9th ed. Vol I, PP-1274. 